\title{
Skin lesions in a patient with epilepsy
}

\author{
Alice Tidman, ${ }^{1}$ Ruth Jones, ${ }^{2}$ SA Holme ${ }^{2}$
}

${ }^{1}$ Medicine for the Elderly, Western General Hospital, Edinburgh, UK

${ }^{2}$ Department of Dermatology, NHS Lothian, Edinburgh, UK

\section{Correspondence to}

Dr Ruth Jones,

ruthjones6@nhs.net

Accepted 6 December 2014

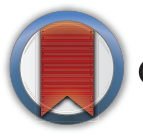

CrossMark

To cite: Tidman A, Jones $R$, Holme SA. BMJ Case Rep Published online: [please include Day Month Year] doi:10.1136/bcr-2014207893

\section{DESCRIPTION}

A 63-year-old woman presented with two smooth, firm, flesh-coloured lumps protruding from the nail folds of her left third and fifth toes (figures 1 and 2).

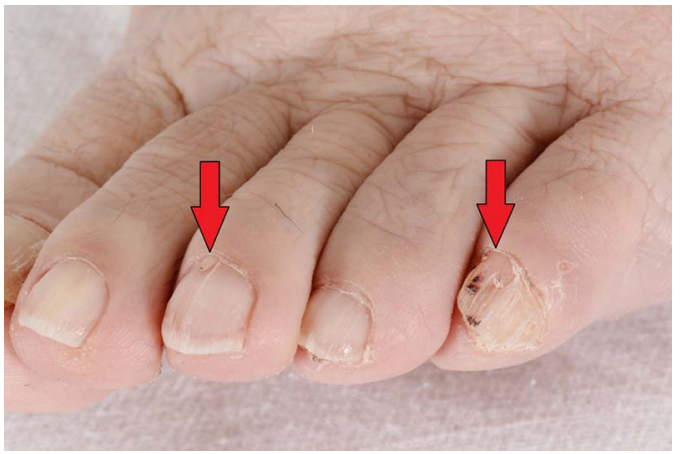

Figure 1 Periungual fibromas on the third and fifth toes (see arrows).

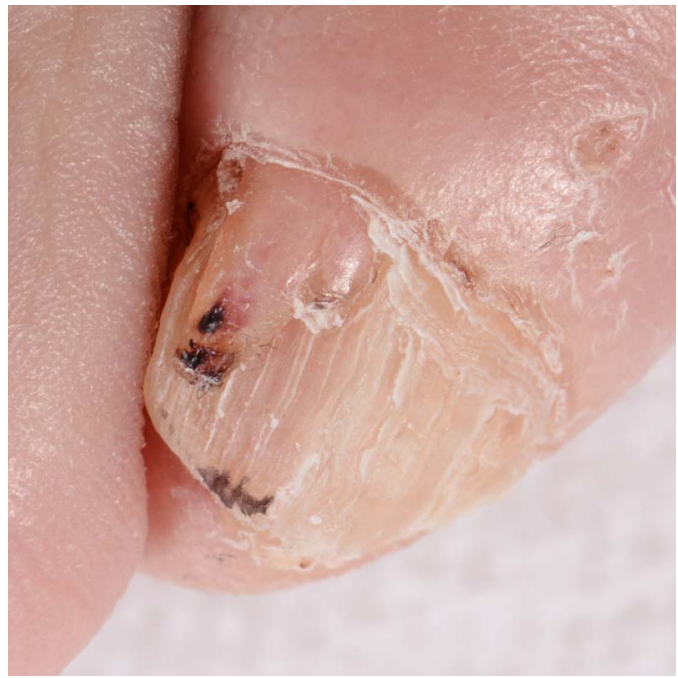

Figure 2 Close-up view of periungual fibroma on fifth toe.
She had a background of epilepsy but had never previously undergone neuroimaging. Periungual fibromas are an important sign of tuberous sclerosis complex, an autosomal dominant multisystem disorder characterised by hamartomas in multiple organs, including skin, brain, eyes, kidney and heart. Skin lesions are found in approximately two-thirds of cases, and also include facial angiofibromas ('adenoma sebaceum'), the shagreen patch and ash leaf-shaped white macules. This patient had a definitive diagnosis of tuberous sclerosis made after a CT brain scan demonstrated subependymal nodules. Despite advances in neuroimaging, it is still important to perform a general examination of the skin, particularly the feet and hands, in any patient presenting with seizures.

\section{Learning points}

- Periungual fibromas are more commonly found on the feet than the hands.

- Think of tuberous sclerosis in a patient with epilepsy and cutaneous lesions.

- Always perform a general examination of the skin, particularly the hands and feet, of any patient presenting with seizures.

Contributors AT wrote the majority of the text component of the case, with supervision from RJ. RJ liased with the patient, organised consent, clinical photographs and edited the final text for submission. SAH highlighted this patient as an interesting case.

Competing interests None.

Patient consent Obtained.

Provenance and peer review Not commissioned; externally peer reviewed.

Copyright 2014 BMJ Publishing Group. All rights reserved. For permission to reuse any of this content visit http://group.bmj.com/group/rights-licensing/permissions.

BMJ Case Report Fellows may re-use this article for personal use and teaching without any further permission.

Become a Fellow of BMJ Case Reports today and you can:

- Submit as many cases as you like

- Enjoy fast sympathetic peer review and rapid publication of accepted articles

- Access all the published articles

- Re-use any of the published material for personal use and teaching without further permission

For information on Institutional Fellowships contact consortiasales@bmjgroup.com

Visit casereports.bmj.com for more articles like this and to become a Fellow 